\title{
PUSAT EDUKASI POLUSI SERTA LINGKUNGAN DAN KANTOR KLHK YANG BEBAS DARI DAMPAK POLUSI UDARA DENGAN METODE GREEN ARCHITECTURE
}

\author{
Farrel Ghazy Primananda Kristiharto ${ }^{1)}$, Timmy Setiawan ${ }^{2)}$ \\ 1)Program Studi S1 Arsitektur, Fakultas Teknik, Universitas Tarumanagara, Ghazyfarrel@gmail.com \\ 2)Program Studi S1 Arsitektur, Fakultas Teknik, Universitas Tarumanagara, timmys@ft.untar.ac.id
}

\begin{abstract}
Abstrak
Polusi udara adalah hal yang sangat banyak menimbulkan kerugian bagi lingkungan maupun makhluk hidup nya itu sendiri, tetapi pada saat ini khususnya hal itu sudah mulai di acuhkan oleh sebagian besar manusia di mana banyak orang yang meremehkan dan acuh juga terhadap masalah ini, yang mana jika di biarkan masalah ini menerus akan mengakibatkan kerugian lebih besar lagi. polusi udara bisa berdampak pada kesehatan manusia khususnya pernafasan juga berdampak terhadap lingkungan, menyebabkan keseimbangan dalam alam rusak, yang mengakibatkan lingkungan hidup rusak, bukan hanya berdampak ke kehidupan binatang tapi juga kehidupan manusia, pada akhirnya jika terus di biarkan kualitas hidup manusia kan turun drastis dan kehidupan akan berubah sepenuhnya, di mana udara bersih dan lingkungan yang sehat tidak lagi di temukan. Oleh karena itu di butuhkannya wadah yang bisa membuat masyarakat peduli terhadap masalah ini, yang mana pada proyek ini adalah pusat edukasi polusi udara dan tentang lingkungan yang mana bangunan ini menerapkan metode green architecture atau arsitektur hijau yang secara garis besar adalah bangunan ramah lingkungan, yang mana bangunan ini bisa menjadi bangunan contoh dari green architecture.
\end{abstract}

Kata kunci: Green architecture; Kantor; Lingkungan; Polusi Udara; Pusat Edukasi

\begin{abstract}
Air pollution is a thing that can cause many disadvantage for environment and the organism in there, however on this day it is starting to be ignored by many people in earth, where many people underestimate this air pollution problem and ignore the environment, and if its leave it that way it will cause a bigger problem, air pollution can cause a health problem for human it can cause a bad impact for respiration. And the ignorance of people for environment can cause the stability in ecosystem. Of which cause decreasing the quality of human life and life will change drastic, where the clean air and healthy environment. Therefore it is needed a place that can make public aware with this problem, which in this project there will be an education centre for air pollution and environment. And this building use a green architecture method, which it can be an example for green architecture building.
\end{abstract}

Keywords: Air Pollution; Education Centre; Environment; Green Architecture; Office

\section{PENDAHULUAN Latar Belakang}

Polusi udara merupakan suatu kondisi kualitas udara yang buruk karena terjadinya pencemaran lingkungan dan merupakan kontaminasi oleh zat - zat yang diakibatkan karena gas, cairan atau limbah padat yang dapat membahayakan kesehatan tubuh manusia. Salah satu masalah yang terjadi pada Indonesia sebagai Negara Berkembang ialah Polusi udara, khususnya di Ibu Kota Indonesia yaitu DKI Jakarta yang mempunyai mobilitas yang terus meningkat yang mengakibatkan dampak dari terjadinya kualitas udara yang buruk. Banyaknya kegiatan yang dilakukan di Ibu Kota menjadi pusat dan daya Tarik untuk mencari nafkah mulai dari berbagai 
macam tingkat ekonomi, Pendidikan hingga pemerintahan yang berpusat di lbu Kota. Aktivitas perkotaan yang sangat padat dan mempunyai waktu yang tidak pernah berhenti, Banyaknya aktivitas kendaraan dan alat-alat industri yang mengeluarkan gas yang mencemarkan lingkungan akan semakin parah pula pencemaran udara yang terjadi. hal ini membuktikan bahwa mempunyai pengaruh buruk yang menyumbang polusi kepada lingkungan yang semakin lama di biarkan akan merusak lingkungan dan memperburuk kualitas hidup manusia itu sendiri. Oleh karena itu kesadaran akan masalah polusi dan menjaga alam seharusnya sudah di tanamkan sejak dini setidaknya generasi penerus membawa perubahan untuk lingkungan hidup yang lebih baik. oleh karena itu arsitek sebagai perencana bangunan yang kebanyakan ada di kota mempunyai peran penting dalam semua masalah itu untuk mengurangi kerusakan alam yang di sebabkan oleh khusus nya dari pembangunan maupun bangunan itu sendiri. pada proyek ini di harapkan bangunan yang di rancang bisa menjadi acuan untuk arsitektur yang lebih ramah kepada lingkungan.

Hal ini dapat dibuktikan pada saat pelaksanan PSBB (Pembatasan Sosial Berskala Besar) memperlihatkan Langit Jakarta kernbali berwarna biru karena berkurangnya kendaraan yang keluar pada Masa PSBB. Polusi udara bertanggung jawab atas kematian dini sebanyak 6.100 jiwa di Jakarta sejak 1 Januari 2020. Sebuah alat baru yang telah diluncurkan oleh Greenpeace Asia Tenggara dan IQ Air AirVisual, yang dapat memperlihatkan dampak dari polusi udara di 28 kota secara real-time di seluruh dunia. Selain menghitung risiko dari kematian dini, situs ini juga menghitung kerugian ekonomi akibat polusi udara. Ibu Kota DKI Jakarta memiliki dampak dari polusi udara yang telah menelan biaya ekonomi RP 21,5 triliun, atau dua kali lipat dari defisit BPJS, dan setara dengan 26\% dari anggaran kota Jakarta tahun 2020.

Meskipun ada Penerapan Pembatasan Sosial Berskala Besar (PSBB) karena COVID-19, kualitas udara di Jakarta tetap dalam kisaran yang sama dengan tahuntahun sebelumnya. Citra satelit dan analisis yang disusun oleh Center for Research on Energy and Clean Air (CREA) mengungkapkan bahwa sementara konsentrasi N02 turun 33\%, tingkat polusi PM2.5 tetap tinggi. Penurunan konsentrasi N02 di Jakarta sebagian besar disebabkan oleh penurunan kegiatan pada sektor transportasi dan industri selama masa PSBB. Namun, sumber pencemar utama seperti pembangkit listrik tenaga batubara yang berlokasi di luar Jakarta, termasuk pembangkit listrik tenaga batubara Suralaya di Banten, terus beroperasi seperti biasa. Khususnya, NOX dari sumber tersebut dapat teroksidasi untuk membentuk PM2.5, yang merupakan partikel mikro yang memiliki periode bertahan lama di atmosfer dan dapat terbang cukup jauh.

Karena lintasan angin yang berlaku, polutan PM2.5 dari pembangkit batubara ini mencapai wilayah Jakarta selama periode PSBB, dan mempengaruhi kualitas udara di kota. Dengan banyak nya dampak merugikan yang di sebabkan oleh polusi udara pemerintah seperti masih belum dapat ditemukan solusinya dengan masalah ini, tidak ada upaya signifikan yang dilakukan pemerintah untuk menghadapi permasalahan ini. Oleh karena itu arsitek mempunyai peran yang cukup penting dalam menghadapi permasalahan polusi udara ini dengan mengurangi atau tidak ikut menambah polusi di udara.

\section{Rumusan Permasalahan}

Memperhatikan latar belakang di atas, maka beberapa permasalahan yang di timbulkan dapat di rumuskan seperti bagaimana dampak yang di berikan oleh pencemaran udara? Bagaimana cara meningkatkan kesadaran masyarakat tentang polusi udara dan lingkungan ? Apakah suatu bangunan arsitektur bisa mengatasi atau mengurangi pencemaran udara? Bagaimana solusi yang dapat di terapkan pada arsitektur untuk mengatasi atau mengurangi pencemaran udara?. 


\section{Tujuan}

Tujuan dari perancangan pusat edukasi dan kantor ini adalah sebagai tempat alternatif sarana hiburan beredukasi untuk meningkatkan kesadaran masyarakat tentang polusi udara; sebagai sarana atau fasilitas perkantoran bagi KLHK dan kantor sewa bagi perusahaan perwakilan pabrik atau yang berkaitan dengan polusi udara; ikut serta mendukung program pemerintah untuk meningkatkan kesadaran masyarakat terhadap polusi udara dengan merancangan bangunan yang ramah lingkungan; sebagai proyek percontohan dalam hal green building atau green architecture yang berdasarkan KLHK.

\section{KAJIAN LITERATUR}

\section{Polusi udara}

Polusi udara diartikan sebagai adanya bahan-bahan atau zat-zat asing didalam udara yang menyebabkan perubahan susunan (komposisi) udara dari keadaan normalnya. Udara didaerah perkotaan yang mempunyai banyak kegiatan industri dan teknologi serta lalu lintas yang padat, udaranya relatif tidak bersih lagi.

Table 1. Sumber dan Standar kesehatan dari zat - zat Pencemar udara Terdapat banyak zat-zat pencemar udara yang dapat diidentifikasi, namun beberapa di antaranya yang utama adalah sebagaimana disajikan dalam tabel di bawah.

\begin{tabular}{|l|l|l|}
\hline PENCEMAR & SUMBER & KETERANGAN \\
\hline $\begin{array}{l}\text { Karbon monoksida } \\
(\mathrm{CO})\end{array}$ & $\begin{array}{l}\text { Buangan kendaraan bermotor; } \\
\text { beberapa }\end{array}$ & $\begin{array}{l}\text { Standar kesehatan: } 10 \mathrm{mg} / \mathrm{m} 3 \\
(9 \mathrm{ppm})\end{array}$ \\
\hline $\begin{array}{l}\text { Sulfur dioksida } \\
(\mathrm{S} 02)\end{array}$ & Panas dan fasilitas pembangkit listrik & $\begin{array}{l}\text { Standar kesehatan: } 80 \mathrm{ug} / \mathrm{m} 3 \\
(0.03 \mathrm{ppm})\end{array}$ \\
\hline Partikulat lainnya & $\begin{array}{l}\text { Buangan kendaraan bermotor; } \\
\text { beberapa proses industri }\end{array}$ & $\begin{array}{l}\text { Standar kesehatan: } 50 \mathrm{ug} / \mathrm{m} 3 \\
\text { selama } 1 \text { tahun; } 150 \mathrm{ug} / \mathrm{m} 3\end{array}$ \\
\hline $\begin{array}{l}\text { Nitrogen dioksida } \\
(\text { N02 })\end{array}$ & $\begin{array}{l}\text { Buangan kendaraan bermotor; panas } \\
\text { dan fasilitas }\end{array}$ & $\begin{array}{l}\text { Standar kesehatan: } 100 \mathrm{pg} / \mathrm{m} 3 \\
(0.05 \text { ppm) selama } 1 \mathrm{jam}\end{array}$ \\
\hline Ozon $(03)$ & Terbentuk di atmosfir & $\begin{array}{l}\text { Standar kesehatan: } 235 \mathrm{ug} / \mathrm{m} 3 \\
(0.12 \mathrm{ppm}) \text { selama } 1 \mathrm{jam}\end{array}$ \\
\hline
\end{tabular}

Sumber: Badan Pengendalian Dampak Lingkungan (Bapendal)

Proses pembakaran bahan bakar minyak seperti diketahui akan mengeluarkan unsur-unsur dan senyawa-senyawa pencemar udara seperti debu, karbon monoksida, hidrokarbon, sulfur oksida, timbal. Senyawa berbagai jenis dari hidrokarbon. Hidrokarbon sendiri merupakan pencemar udara yang dapat berupa gas, cairan maupun padatan. Dinamakan hidrokarbon karenapenyusun utamanya adalah atom karbon dan atomhidrogen yang dapat terikat (tersusun). Hidrokarbon merupakan teknologi umum yang digunakan untuk beberapa senyawa organik yang diemisikan bila bahan bakar minyak dibakar. Sumber langsung dapat berasal dari berbagai aktivitas perminyakan yang ada, seperti ladang minyak, gas bumi.

\section{Sumber polusi di Jakarta}

CREA adalah organisasi penelitian independen yang mempelajari tren, penyebab, solusi, dan dampak kesehatan dari polusi udara. Analisis CREA menyebutkan bahwa sumber dari proses buangan yang mencemari ruang udara Jakarta berasal dari pembangkit listrik batu bara, pabrik, dan fasilitas industri lainnya, tercatat bahwa pencemaran udara yang buruk di jakarta adalah pembungan yang berasal dari Sulfur Dioksida (SO2), Nitrogen dioksida atau gas rumah kaca (Nox) dan partikular PM 2,5 disimpulkan bahwa jauh lebih tinggi pada wilayah jakarta. 


\section{Dampak dari polusi udara}

Polusi udara tentu memberikan dampak buruk pada segala bidang seperti halnya kesehatan,terdapat bukti yang kuat bahwa paparan polusi udara jangka panjang meningkatkan risiko terinfeksi COVID-19 yang parah hingga menyebabkan kematian. Paparan polusi udara kronis dikaitkan dengan penyakit seperti hipertensi, diabetes, penyakit kardiovaskular, dan penyakit paru-paru kronis, Pasien dengan kondisi ini memiliki risiko lebih besar dirawat rumah sakit bila terinfeksi COVID-19. selain dampak bagi kesehatan, polusi udara juga berdampak pada lingkungan.

\section{Pusat}

Dalam KBBI pusat berarti tepat yang letak nya di bagian tengah, atau juga bisa berarti pokok pangkal yang jadi pumpunan berbagai hal, dalam jurnal ini merujuk padad edukasi.

\section{Edukasi}

Edukasi adalah suatu proses interaktif yang membuat terjadinya upaya untuk menambah pengetahuan baru, sikap, serta kemampuan melalui praktik dan sebuah pengalaman.

\section{Green Architecture}

PERMEN LH 08/2010 mendefinisikan green building di dalam pasal 1 butir 1 sebagai berikut: "bangunan ramah lingkungan (green building) adalah suatu bangunan yang menerapkan prinsip lingkungan dalam perancangan, pembangunan, pengoperasian, dan pengelolaannya dan aspek penting penanganan dampak perubahan iklim".

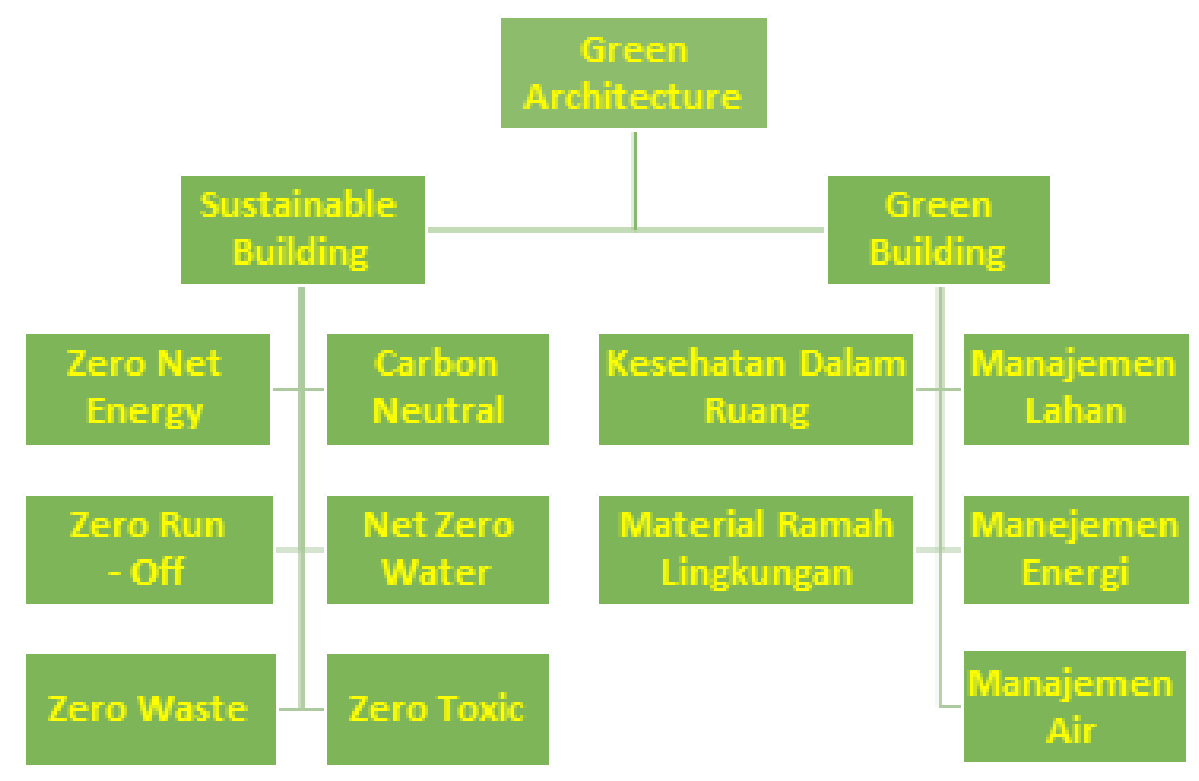

Gambar 1. Green Building Menurut Peraturan Menteri Negara Lingkungan Hidup Nomor 08 Tahun 2010 Tentang Kriteria Dan Sertifikasi Bangunan Ramah Lingkungan Sumber: Kementrian Lingkungan Hidup dan Kehutanan

\section{Edukasi Polusi \& Arsitektur Hijau}

Edukasi polusi berarti proses pembelajaran mengenai hal-hal tentang polusi, sedangkan arsitektur hijau adalah bangunan yang ramah dengan lingkungan. Bangunan pusat edukasi polusi dengan metode arsiektur hijau menunjukkan keterkaitannya dimana bangunan arsitektur hijau berperan dalam pencegahan polusi dalam bidang arsitekturan, yang mana bisa menjadi salah satu solusi mikro yang di lakukan dalam mengurangi polusi. 


\section{METODE}

Perancangan tugas akhir ini menggunakan metode Analisa kualitatif dengan cara mengembangkan, menciptakan, menemukan konsep dan teori. Metode analisis data kualitatif di lakukan berdasarkan logika dan argumentasi yang bersifat ilmiah. Metode penelitian merupakan salah satu faktor yang cukup penting dalam melakukan suatu penelitian, karena pada dasarnya metode penelitian merupakan cara ilmiah untuk mendapatkan data dengan tujuan dan kegunaan tertentu. Metode penelitian adalah usaha untuk menemukan, mengembangkan, dan menguji suatu kebenaran pengetahuan dengan cara-cara ilmiah. Oleh karena itu, metode yang digunakan dalam suatu penelitian harus tepat. Perancangan tugas akhir ini menggunakan metode Analisa kualitatif dengan cara mengembangkan, menciptakan, menemukan konsep dan teori. Metode analisis data kualitatif dilakukan berdasarkan logika dan argumentasi yang bersifat ilmiah.

Menurut Arikunto (1998: 309) penelitian kualitatif dimaksudkan untuk mengumpulkan informasi mengenai status suatu gejala yang ada, yaitu keadaan gejala menurut apa adanya pada saat penelitian itu dilakukan. Oleh karena itu, penelitian kualitatif mampu mengungkap fenomena - fenomena pada suatu subjek yang ingin diteliti secara mendalam. Peneliti kualitatif percaya bahwa kebenaran adalah dinamis dan dapat ditemukan hanya melalui penelaahan terhadap orang-orang melalui interaksinya dengan situasi sosial mereka (Danim, 2002). Metode dari penelitian ini menggunakan Studi Kasus. Penelitian studi kasus adalah studi yang mengeksplorasi suatu masalah dengan batasan terperinci, memiliki pengambilan data yang mendalam, dan menyertakan berbagai sumber informasi. Penelitian ini dibatasi oleh waktu dan tempat, dan kasus yang dipelajari berupa program, peristiwa, aktivitas, atau individu

\section{DISKUSI DAN HASIL}

\section{Analisis}

Seperti yang di ketahui berdasarkan landasan teori bahwa mayoritas penyumbang polusi udara berasal dari pabrik dan kendaraan bermotor, oleh karena itu perlu beberapa solusi untuk merespon polusi yang berasal dari dua sumber tersebut, oleh akrena itu tapak terpilih berada di daerah Pulo Gadung, di maka di kawasan industri yang aktif dan juga mobilitas kendaraan bermotor yang tinggi di karenakan ingin menjaddikan bangunan ini sebagai bangunan percontohan dari arsitektur hijau yang ramah lingkungan dan menyaring polusi secara mikro. Dengan berdasarkan masalah yang ada muncul lah berbagai solusi untuk merespon masalah tersebut seperti penghijauan sebagai buffer polusi sebagai penghalang pertama polusi, air purifier sebagai penyarng udara kotor yang masuk ke dalam tapak, arsitektur hijau sebagai metode yang ramah lingkungan guna mengurangi polusi, bentuk bangunan $v$ guna menarik segala udara masuk untuk kemudian di saring dengan penghijauan dan air purifier, blower dan meriam air untuk memecah polusi, dan membuat pengguna menggunakan tranportasi umum guna mengurangi polusi akibat kendaraan bermotor.

\section{Tapak}

Tapak berada di daerah Pulo Gadung. Alasan mengapa proyek ini berada di Pulo Gadung di karenakan tapak ini berada di Kawasan industri yang akan sesuai pada konsep proyek ini yaitu bangunan anti polusi udara, yang mana pada kawasan industri ini polusi udara masih menjadi masalah utama yang berdampak langsung pada warga di sekitar oleh karena itu dengan adanya bangunan ini menjadi wadah dan membawa angin segar bagi warga di sekitar. Seperti yang ada pada berita media cetak maupun online polusi udara yang di hasilkan oleh Kawasan industri Pulo Gadung sangat banyak dan mengganggu, tentu ini memberi dampak negatif terhadap masyarakat sekitar yang bisa berpengaruh kepada kesehatan khususnya usia rentan. 


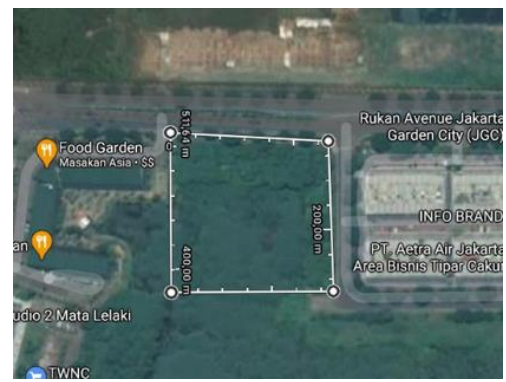

Gambar 2. Tapak

Sumber: Dokumen Pribadi Mengadaptasi Google Earth

\section{Green building}

Green building merupakan gabungan atau kombinasi efisiensi energi dan dampak material pada penghuni. Suatu konsep penilaian atas bangunan gedung yang ramah terhadap lingkungan serta berkonstribusi dalam peningkatan kesehatan produktivitas penghuninya. Cara ini bisa di gunakan sebagai respon dari polusi dan juga ramah dengan lingkungan dimana dengan menerapkan green building pada bangunan bisa memberi kontribusi positif bagi lingkungan sekitar serta hemat energi. Seperti halnya penggunaan solar panel sebagai sumber energi yang mana bisa menghemat energi lebih banyak mengingat juga penggunaan air purifier yang cukup banyak bisa meng-cover energi yang digunakan olehnya. Kemudian memanfaatkan energi alami seperti matahari sebagai pencahayaan jalami pada bangunan dengan merancang bukaan yang tepat dan juga cross ventilation sebagai pendingin ruangan sehingga bisa mengurangi penggunaan alat pendingin ruangan secara berlebih. Dari segi material juga di perhatikan, dengan menggunakan material yang ramah lingkungan di mana pada saat pemasangannya tidak menimbulkan banyak polusi, jika material rusak mudah untuk di perbaiki, dan jika material itu hancur bisa di serap oleh tanah atau ramah lingkungan.

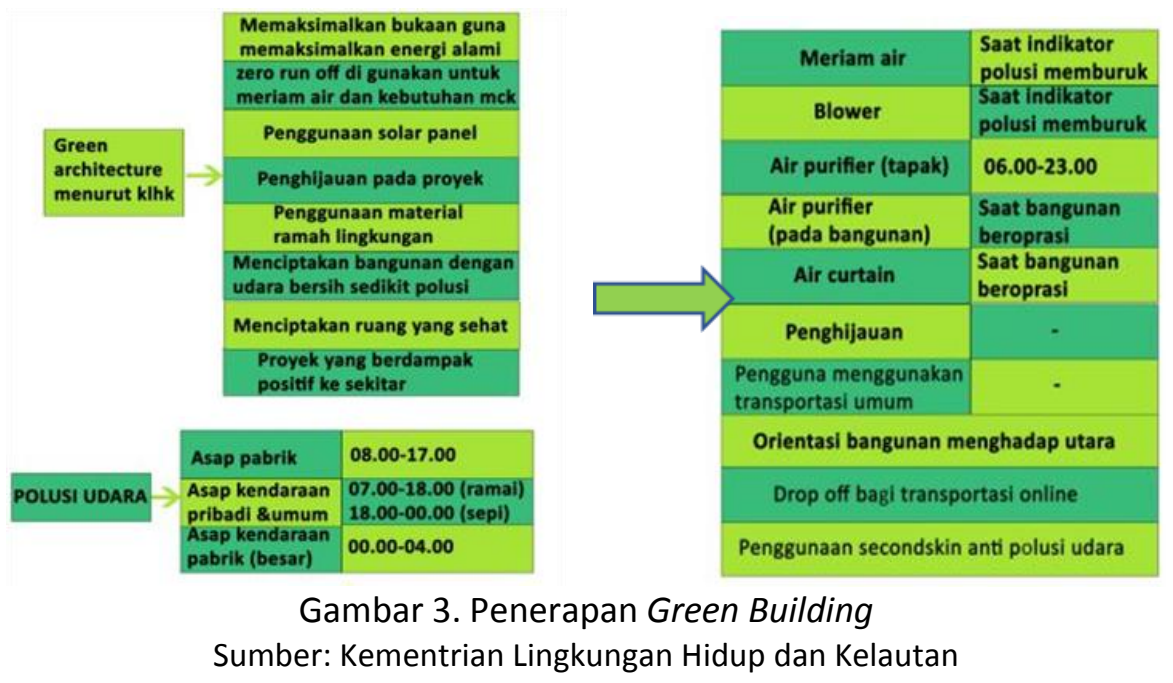

\section{Air Purifier}

Penggunaan penyaring udara bisa menjadi salah satu cara yang cukup efektif untuk membersihkan udara pada bangunan maupun sekitar, karena udara kotor yang di hasilkan dan mengandung polusi bisa langsung di proses dan menjadi udara bersih yang aman di hirup tanpa memberi dampak negatif. Sistem kerja alat ini adalah dengan menyedot udara dari luar yang kotor melewati filter yang terpasang pada alat kemudian udara yang sudah tersaring menjadi udara bersih langsung di distribusikan ke dalam bangunan maupun lingkungan sekitar. Penggunaan alat ini sebagai respon dari polusi udara di Jakarta merupakan pilihan tepat, karena beberapa negara sudah menggunakan penyaring udara untuk meningkatkan kualitas udara. 


\section{Bufffer dan Penghijauan}

Dalam masalah polusi udara pohon dan tumbuhan lainnya tentu mempunyai peran yang cukup penting dalam mengatasi masalah ini. Menurut penelitian pohon juga bisa menurunkan temperatur udara dan dampak positif lainnya seperti taman kecil bisa mengurangi temperature sebanyak $7^{\circ} \mathrm{C}$; pohon pada pinggiran jalan bisa mengurangi temperature sampai $3,9^{\circ} \mathrm{C}$; penghijauan pada atap bangunan bila di gunakan sederet bangunan bisa mengurangi temperatur $4,4^{\circ} \mathrm{C}$; tumbuhan bisa mengurangi gas buangan dan partikel di udara; tumbuhan bisa mengurangi konsentrasi nitrogen oksida sampai 57\%; tumbuhan juga berdampak baik bagi psikologis; Pohon pada bangunan di maksudkan sebagai barrier yang bisa menghalau polusi udara ke dalam bangunan dan juga mengurangi polusi udara di sekitarnya.

\section{Penggunaan Transportasi Umum}

Seperti yang telah di jabarkan di atas bahwa kendaraan motor pribadi menyumbang polusi udara yang cukup banyak pada polusi udara di kota Jakarta. Bisa di lihat buktinya pada saat penerapan PSBB dan PSBB usai di kota Jakarta. Langit Jakarta biru tidak tertutup kabut polusi dan asap kendaraan pada saat PSBB dan kembali tertutup asap pada saat PSBB selesai. Oleh karena itu membuat pengguna bangunan menggunakan transportasi umum dan tidak menggunakan kendaraan bermotor pribadi bisa mengurangi jumlah kendaraan bermotor yang ada di jalanan dan bisa mengurangi jumlah polusi udara yang di hasilkan oleh gas buangan kendaraan bermotor.

\section{Penggunaan Blower dan Meriam Air}

Meriam air dan blower pada hal ini akan bekerja sama diamana saat indikator polusi udara menyatakan udara tidak sehat dengan kadar polusi yang tinggi Meriam air pada puncak bangunan akan di nyalakan sebagai hujan buatan dan saat polusi jatuh di bawa oleh air kemudian di semprot menggunakan blower untuk memisah menjadi lebih kecil dan menghilangkan polusi untuk di serap ke dalam tanah. Meriam air ini menggunakan air daur ulang dari air bekas pakai maupun menampung air hujan kemudian diolah dan disaring menjadi air bersih kemudian di gunakan untuk meriam air menyiram polusi.

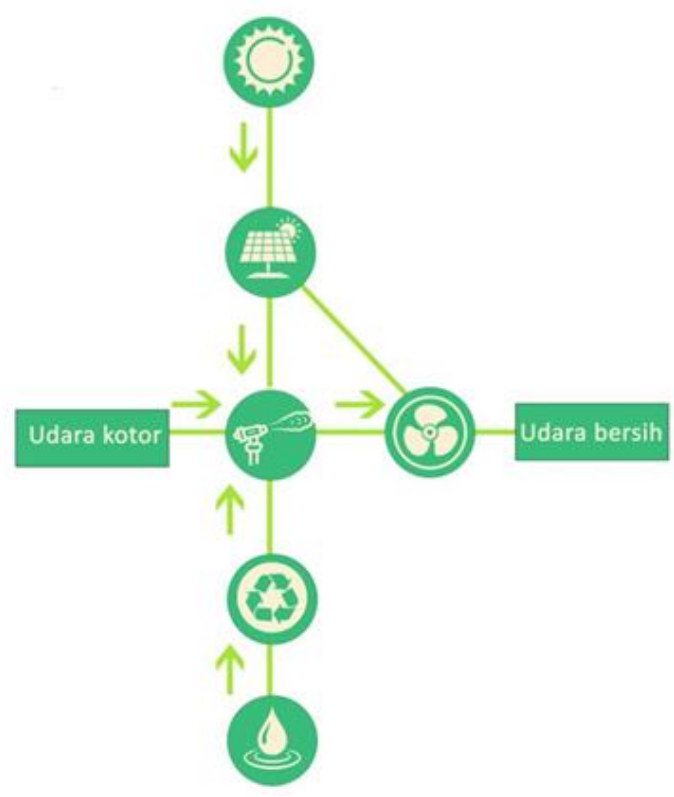

Gambar 4. Alur Blower dan Meriam Air Sumber: Penulis, 2021 


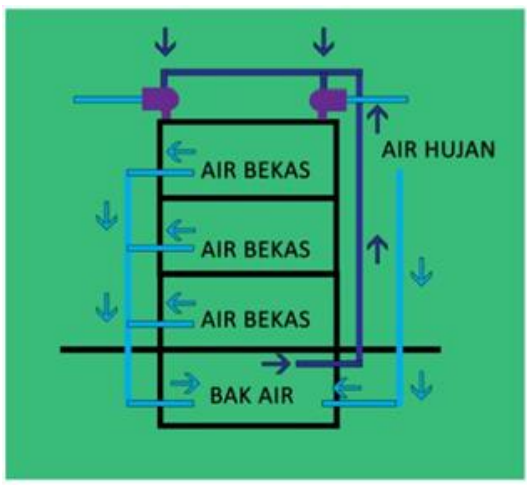

Gambar 5. Distribusi Air Meriam Sumber: Penulis, 2021

\section{Bentuk bangunan V}

Bentuk bangunan seperti ini dapat menangkap polusi dari luar tapak ke dalam kemudian di saring untung menjadi udara yg lebih bersih dari polusi, dengan bentuk seperti ini juga menggunakan cara cross ventilation yang mana bisa memaksimalkan pendingin alami dari udara yang ada.
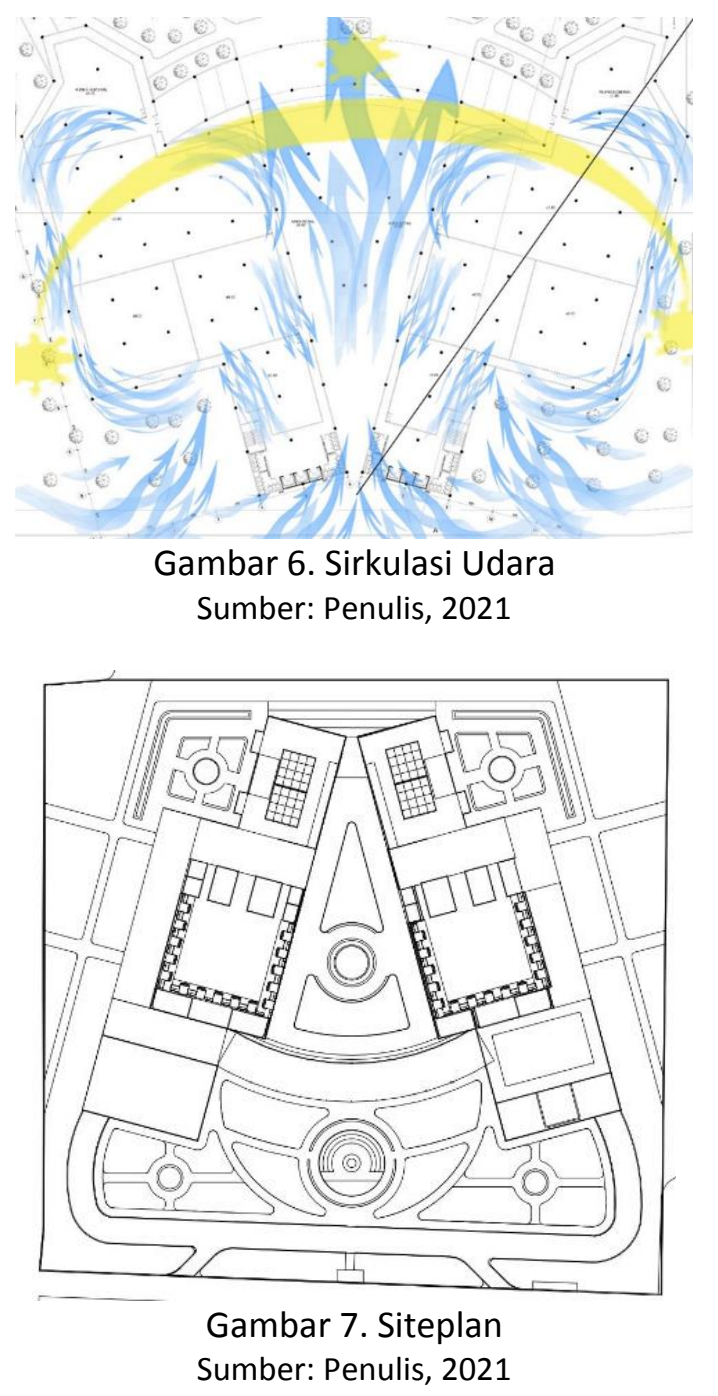


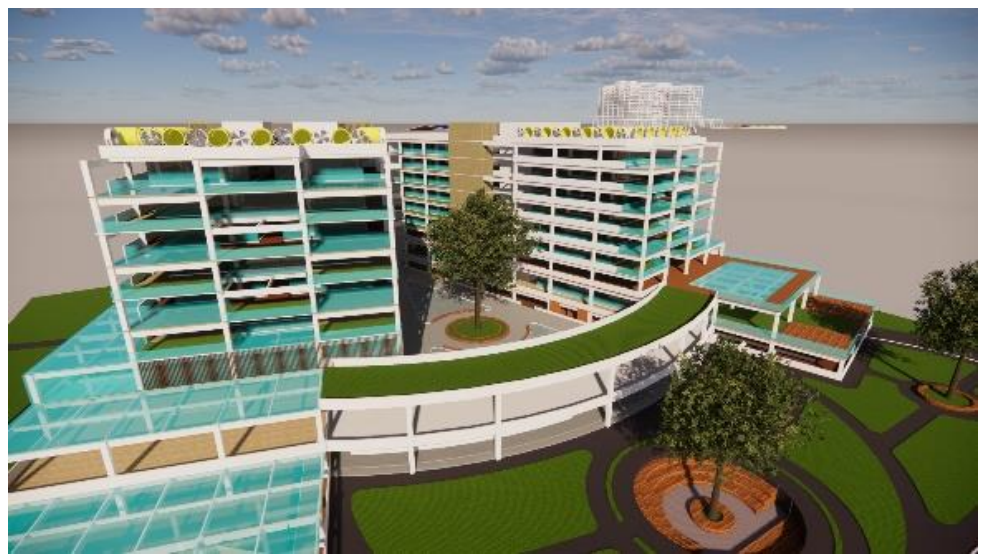

Gambar 8. Eksterior

Sumber: Penulis, 2021

\section{KESIMPULAN DAN SARAN}

\section{KESIMPULAN}

Polusi udara tentunya menjadi hal yang sangat krusial pada kehidupan manusia, banyaknya dampak yang diberikan oleh masalah tersebut seperti salah satunya dampak kesehatan bagi manusia bahkan sampai kepada alam, namun pada saat ini masyarakat bahkan pemegang wewenang pemerintahan seakan tidak peduli akan masalah polusi udara ini. Dalam proyek ini menggunakan berbagai respon solusi terhadap polusi dengan menggunakan konsep arsitektur hijau, menurut KLHK konsep arsitektur hijau lebih ramah lingkungan dan berperan dalam mengurangi polusi yang ada, kemudian penggunaan transportasi umum untuk pengguna bangunan yang bisa mengurangi polusi udara dari kendaraan bermotor, selanjutnya ada penggunaan blower dan meriam air yang mana berguna saat indeks polusi udara memburuk, kedua mesin ini dinyalakan guna menurunkan polusi dan memecahnya, setelah itu ada buffer penghijauan pada tapak, buffer ini berguna untuk menangkal polusi udara yang masuk ke dalam tapak dengan diserap oleh penghijauan dan untuk penggunaan air purifier juga cukup membantu dalam masalah ini guna membersihkan udara lebih bersih lagi setelah udara kotor melewati penghijauan.

\section{Saran}

Karena masalah polusi ini adalah masalah makro dan tidak bisa di selesaikan secara mikro oleh karena itu di butuhkan nya kerja sama dari berbagai pihak untuk merespon masalah polusi yang terjadi, agar nantinya tidak memberikan dampak buruk pada masa yang akan datang.

\section{REFERENSI}

Arikunto, S. (1998). Prosedur Penelitian Suatu Pendekatan Praktek. Jakarta: PT. Rineka Cipta.

Buanawati, T.T., Huboyo, H.S., Samadikun, B.P., (2017). Estimasi Emisi Pencemar Udara Konvensional (Sox, Nox, Co, dan Pm) Kendaraan Pribadi Berdasarkan Metode International Vehicle Emission (Ive) di Beberapa Ruas Jalan Kota Semarang. Jurnal Teknik Lingkungan 6, 112.

Peraturan Menteri Lingkungan Hidup dan Kehutanan Republik Indonesia. (2019). Tentang cara penerapan label ramah lingkungan hidup untuk pengadaan barang dan jasa ramah lingkungan hidup (nomor P.5/MENLHK/SETJEN/KUM.1/2/2019). Jakarta: KLHK Potter PA., Perry AG. (2005). Buku Ajar Fundamental Keperawatan Konsep (definisi edukasi), Proses dan Praktik Edisi 4. Jakarta: EGC.

Wardhana, A.W. (2004). Dampak Pencemaran Lingkungan. Edisi Revisi. Yogyakarta: Andi Offset Kompas.com, (2020), PSBB Transisi Jakarta Nomor Dua Penyumbang Polusi Udara Dunia, Kok Bisa?, diunduh 10 Agustus 2020, 
https://www.kompas.com/sains/read/2020/06/16/123400723/psbb-transisi-jakartanomor-dua-penyumbang-polusi-udara-dunia-kok-bisa?page=all

The Times of India, 2018, Bengaluru: Cubbon Park to get air purifiers to tackle air pollution, diunduh 10 Agustus 2020, https://timesofindia.indiatimes.com/city/bengaluru/bengalurucubbon-park-to-get-air-purifiers-to-tackle-air-pollution/articleshow/66450619.cms

Tribun-Medan.com, 2015, China Pakai "Meriam Air" Untuk Kurangi Polusi Udara, diunduh 26 Juli 2020, https://medan.tribunnews.com/2015/12/28/china-pakai-meriam-air-untukkurangi-polusi-udara 